\title{
Reflections from Pre-Service Teachers' Mathematics Teaching Process
}

\section{Öğretmen Adaylarının Matematiği Öğretme Süreçlerinden Yansımalar}

\author{
Müjgan BAKİ Selahattin ARSLAN**
}

- Received: 07 January $2015 \bullet$ Accepted: 22 December $2015 \bullet$ Published: 31 October 2016

\begin{abstract}
Pedagogical Content Knowledge (PCK) has been considered to be the most important factor for identifying the role of the teacher in carrying out effective teaching. This paper examines, with respect to the components of PCK, the types of difficulties that a group of pre-service teachers encountered during the process of designing teaching activities. For this purpose, 8 pre-service teachers $(4$ elementary mathematics and 4 classroom teachers) are observed whilst teaching mathematics during the Teaching Practicum course and are interviewed. The study reveals that both groups of pre-service teachers had similar problems in teaching practices. Pre-service teachers experienced difficulties in determining the activities with regard to prior knowledge of the students, deciding the difficulty level of the activities and sorting them, informing students about the purpose of the activities, conducting activities according to their perceived purposes and making transitions between activities.
\end{abstract}

Keywords: Pedagogical Content Knowledge, pre-service teachers, student's activity.

ÖZ: Alanı Öğretme Bilgisi (AÖB) etkili öğretim yapan bir öğretmenin sahip olduğu en temel bilgilerdendir. Bu çalışma, AÖB'nin bileşenleri bağlamında öğretmen adaylarının karşılaştığı zorlukları incelemeyi amaçlamaktadır. Bu amaç doğrultusunda 4'ü sınıf, 4'ü ilköğretim matematik olmak üzere 8 öğretmen adayı Öğretmenlik Uygulaması dersi kapsamında gözlenmiş ve bu adaylarla mülakatlar yapılmıştır. Çalışmada her iki gruptaki öğretmen adaylarının benzer problemler yaşadıkları ortaya konulmuş̧tur. Bu bağlamda, öğretmen adaylarının öğrenciye ulaşma, öğrenci önbilgisine uygun etkinlik belirleme ve uygulama, etkinlikleri zorluk derecesine göre siralama, öğrencileri etkinliklerin amacından haberdar etme, etkinlikleri toparlama ve etkinler arası geçiş yapma gibi hususlarda zorluklar yaşadıkları sonucuna varılmıştır.

Anahtar sözcükler: Alanı öğretme bilgisi, öğretmen adayı, öğrenci etkinliği.

\section{INTRODUCTION}

Knowing mathematical concepts is not enough to teach mathematics (Baki, Baki, \& Arslan, 2011; Borko \& Putnam, 1996). In order to teach a field in general or mathematics in particular, a teacher should have the skill of making knowledge understandable for the students. As teachers' knowledge and their competencies play a key role in students' achievement (Leong, Meng \& Abdul Rahim, 2015), a crucial problem of teacher education is to determine knowledge and competencies a teacher should have in order to teach effectively (i.e., knowledge base for teaching) (Fernandez, 2014). Shulman (1986) defines the knowledge that helps a teacher make any information understandable for learners as Pedagogical Content Knowledge (PCK). Therefore, PCK can be seen as the process of organizing, adapting and presenting content and the pedagogy in a harmony (Shulman, 1987).

PCK has been considered as the most important component in identifying the role of the teacher in carrying out effective teaching (Ann, Kulm \& Wu, 2004; Ball, 1990; Magnusson, Borko \& Krajik, 1999; Nilsson, 2008), and many researchers have conducted studies in order to comprehend PCK (Ball, Thames \& Phelps, 2008; Grossman, 1990; Hashweh, 2005; Loughran, 2006; Magnusson et al., 1999; Shulman, 1986, 1987; Van Driel, Verloop \& de Vos, 1998). Shulman (1986) divides PCK in two components as "students understanding" and "instructional strategies and representations". Grossman (1990) expanded Shulman's definition by adding

\footnotetext{
*Asst. Prof., Karadeniz Technical University, Fatih Faculty of Education, Trabzon, mujganbaki@gmail.com

${ }^{* *}$ Assoc. Prof., Karadeniz Technical University, Fatih Faculty of Education, Trabzon, selaharslan@ gmail.com
} 
"curriculum knowledge". Magnusson et al. (1999) extended PCK by basing on Grossman's structure and added "testing and evaluation" knowledge. Furthermore some researchers claimed that beliefs affected PCK (Ann, Kulm \& Wu, 2004; Fennema and Franke, 1992).

Ball et al. (2008) used the term Mathematical Knowledge for Teaching to describe the knowledge needed to teach mathematics. They divide this knowledge into two as Content Knowledge and PCK, and divide the latter into three as "knowledge of content and students", "knowledge of content and teaching", and "curricular knowledge."

Despite the unanimity in the importance of PCK, there is still no consensus on what it is (Fernandez, 2014) and researchers included different components into the frame of PCK. Yet, there are two components that researchers agree upon (Park \& Oliver, 2008) and, which appeared to be fundamental in PCK (Chan \& Yung, 2015): i) Knowledge of Students which consists of knowing prior knowledge, prejudgments, difficulty of understanding, and misconceptions of students (Ball, Thames \& Phelps, 2008; Fennema and Franke, 1992; Marks, 1990; Shulman, 1986, 1987); and ii) Knowledge of Organization and Presentation of the Lesson which includes selecting, sequencing, and applying learning activities, giving appropriate teaching explanations, asking effective questions while arranging learning environments (Ball \& Bass, 2003; Ball \& Mcdiarmind, 1990; Grossman, 1990; Marks, 1990; Shulman, 1986, 1987; Staley, 2004). Effective explanations make learning process easier for the learners and include, in addition to fine mathematical knowledge, arranging exhaustive, meaningful, and comprehensive mathematical explanations, using appropriate representations and explaining the meaning of the of the performed operations (Ball \& Bass, 2003; Charalambous, Hill \& Ball, 2011).

As can be deduced from the brief literature presented so far, PCK plays an important role in mathematics teaching while Organization and Presentation of the Lesson is a main component of PCK. The following two shape this component: i.) Teachers' selecting, sequencing, applying activities during the organization of learning environments and ii.) Such teaching activities as determining how to present and provide educational explanations and appropriate examples. Based on this, observing how activities are prepared, applied, and monitored in class is a good opportunity to determine teachers' or candidate teachers' practices that reflect PCK.

Preparing and monitoring students' activities are considered to be the responsibility of the teacher. However a review of the literature demonstrated that pre-service teachers (PSTs) experienced some difficulties on this issue. For example, Yeşildere and Akkoç (2010) found out that although PSTs' preparation for the lesson seemed to be proper, they did not use it in an effective manner during their practices. Also, the authors emphasized that PSTs had problems with sorting their activities in which the students might have some difficulties. In a study conducted with three mathematics PSTs, who had a solid basis in mathematics, Mapolelo (1999) demonstrated that they did not have sufficient competence in choosing and implementing activities and in making effective instructional explanations to increase students' understanding. Similarly, Artzt and Armour-Thomas (1999) found out that if PSTs do not have in-depth mathematical knowledge related to the topic, they are unable to regulate their activities or make proper instructional explanations, and thus, end up conducting teacher-centered lessons as a way out.

Although the literature review demonstrates that PSTs experience some problems during their teaching experiences, these problems are not adequately explored and discussed in depth regarding the components of PCK. Based on that, this study was conducted to illustrate the difficulties that PSTs encounter during the process of teaching activities that they have designed. Accordingly, we addressed the following question in our study: What kind of difficulties do PSTs experience when they apply learning activities that they designed in order to teach mathematics? 
This study is different from previous studies in the sense that it focuses on the 'organization and presentation of the lesson' component of PCK and explains what could be the difficulties PSTs experience in choosing and applying activities.

\section{METHOD}

The study was conducted, as part of the Teaching Practicum course, with 4 pre-service elementary mathematics teachers (coded as MPST1, MPST2, MPST3, and MPST4) teaching $6^{\text {th }}$ and $7^{\text {th }}$ grades and 4 pre-service classroom teachers (coded as CPST1, CPST2, CPST3, and CPST) teaching $4^{\text {th }}$ and $5^{\text {th }}$ grades. CPST2 and MPST4 are male and the others are female.

The PSTs volunteered and were aware of taking part in the study. At the first meeting, an explanation about ethical guidelines was given to the PSTs, they were informed about the purpose of the study and assured about the confidential treatment of their data. All PSTs provided verbal informed consent. Additionally, they were told that they may withdraw from the study at any time.

Teaching Practicum course plays a significant role in PSTs' process of increasing their PCK, because these experiences provide familiarity with authentic classroom (Lowery, 1998). Indeed, during application process, PSTs find opportunities to combine theory and practice while encountering the complexity of classrooms.

During their training in education faculties, PSTs take courses related to general culture, subject matter, general pedagogy, and pedagogical content in a period of 4 years. MPSTs attended courses, such as Instructional Technologies and Material Design, Special Teaching Methods I-II, Classroom Management, and School Experience, whereas CPSTs attended courses, such as Teaching Principles and Methods, Classroom Management, and Mathematics Teaching I-II.

Teaching Practicum course is in $4^{\text {th }}$ grade in which PSTs visit schools for 12 weeks. The course is performed under a collaborative supervision of a faculty member (i.e. Teacher educator) and a teacher from the school. Teacher educator gathers the PSTs together in order to discuss what they did in their school and visits PSTs' classes in order to evaluate their practices in schools and gives them feedback. Teachers in the school inform PSTs about the learning outcomes that they are going to prepare and help them for general matters.

When PCK is considered, teachers' knowledge, beliefs and actions, as well as the reasons for their actions, should be evaluated and understood (Baxter \& Lederman, 1999). Thus, the data in this study were collected through various sources including observations, semi-structured interviews (conducted on the days of the practicum at the schools to obtain daily reflections), field notes and lesson plans.

Observations are highly reliable for measuring PCK of (prospective) teachers during their pedagogical activities because observations reflect teachers' explanations, illustrations, actions, behaviors and calculations in detail (Hill, Sleep, Lewis \& Ball, 2007). In this study, each PST was observed for two class hours on different days. The in-class interactions during the observations were digitally recorded and transcribed. The researchers took clear notes of the instances when PSTs had difficulties in dealing with students' responses and some other problematic issues related to the learning and teaching due to insufficient mathematical PCK that may result in not reaching the students, loosing classroom management, not being able to reach teaching goals and the lesson to be ineffective. Observations, field notes, interviews and lesson plans were examined and analyzed all together, and several themes were determined via inductive method. 


\section{FINDINGS}

The difficulties encountered will be examined through a discussion of how the teaching activities, prepared by the PSTs, were planned and applied. These difficulties are explored under three main themes:

\subsection{Selecting and Ordering Activities}

As it has been explained above, selecting and ordering activities during instruction is characterized as an important element of PCK. Our study demonstrated that when PSTs do not prepare the organization and order the activities for teaching a subject in an appropriate manner, they have difficulties with students in the classroom. The process of applying activities becomes problematic, when PSTs cannot choose the first activity appropriately, they do not order the activities from easy to difficult, and they ignore the level and prior knowledge of the students. As a result, it becomes difficult for the student to understand the subject and achieve the desired outcome. Some instances from our observation are presented in the following:

Having sequenced the activities, CPST2 introduced angles' types as following: First, he reminded students the concept angle and showed them how to measure an obtuse angle with a protractor. Afterwards, he asked students to measure some angles on a worksheet. Later on, he made students figure out the right angle. He asked students what kind of angle is $30^{\circ}$ one. The CPST2's explanation in the classroom was as follows:

Do you know the measure of a right angle? Everyone! Look at the activity. Do you see the 90-degree angle? [...] Look at the right angle. Look at the measure of the right angle. Children, we call the 90-degree angle a right angle. [...] Yes, what do we call the 30degree angle? Presumably, 30 degrees is smaller than 90 degrees!

After this explanation, the students all answered that "it was an acute angle." CPST2 asked everyone to look at the angles presented on their papers, referring to the acute angles in the activity and then asked them "What is an acute angle like?". When there was no response from the class, CPST2 continued his explanations: "Angles from 0 to 90 degrees are acute angles." and right after that he stated that "Since the 120 degree angle is larger than the 90 degree one, we call it an obtuse angle."

At the beginning of the interaction, based on their measures CPST2 had tried to make students comprehend the types of angles by question-answer method, yet he continued the lesson using a teacher-centered approach and explained the types of angles directly, because the students failed to answer. Later, he started asking questions about the measures of angle types as though they had learnt the subject.

How do you define an acute angle? [...]We stated it in the beginning of the lesson. You listened to me. What was the measure of an acute angle? [The students were silent.] I assume that you did not listen to me.

CPST2 could not get the answers he expected as the students did not understand the subject. Indeed, when CPST2 started to work on the questions on the worksheet, the students started asking questions. They were able to determine the types of angles by their appearance, but it turned out that they did not understand their measures. If CPST2 had associated the appearance of the angle types with their measures, the subject would have been much more comprehensible for the students, since learners could determine angle types by their appearances in the $3^{\text {rd }}$ grade. If he had continued the lesson with activities on angle types by measurements after his activity on angles by appearance, he might not have experienced this problem. CPST2 asked students to form different types of angles using their bodies. We think that this activity should have been performed before finding out the measurement of the angle, as the learners were required to model the angle in this activity. Consequently, the lesson was not beneficial for 
the students and they did not comprehend the types of angles. CPST2 explained this in the interview as: "The concepts of obtuse angle and acute angle weren't emphasized enough because students asked questions on this matter."

Based on CPST2's example, we can say that deficiencies regarding prior knowledge of the students and providing tangible examples in the beginning of the lesson negatively affected the practice of the PST.

As for MPST1, she tried to perform "let's build a circle" as the first activity. This activity was related to the $7^{\text {th }}$ grade learning outcome "To determine the features of a circle." She started the lesson by asking the students to put their compass on the desk and then she gave the following definition: "a circle is the set of points which are equidistant to a fixed point in the plane." After that, she moved on the following activity:

Pay attention, and everyone! Prepare your compass. Those who do not have a compass can borrow from their friend after they are done with drawing. [...] Open the last page of your worksheet that has an isometric dot grid, and determine a fixed point on that grid. [...] Put the tip of your compass to the fixed point, determine a unit, it might be 3 or 4 units.

She intended to teach her students how to draw a circle with a compass and the features of a circle. However neither her definition of a circle nor her instructions was comprehensible to the students. For instance, the expression "set of points which are equidistant" was completely an unfamiliar statement for the students and it was quite difficult for them to infer from this statement that one tip of the compass would be on the points of the circle.

By the time MPST1 began again explaining how to use a compass, the students had lost interest. It was quite difficult for her to regain their attention. The students were trying to follow the demonstration and to use the compass themselves; consequently, they were missing what MPST1 was saying in the meantime. Therefore, most of the students could not draw the circle. Since the majority of the students struggled with performing both tasks at the same time, the activity was concluded and students did not form a circle.

Even though MPST1 selected and applied an appropriate activity in the beginning of the lesson, she failed to complete the lesson successfully. She never anticipated that students would have problems using the compass. Her presumption of students being able to use the compass caused difficulties in the application of the activities. She expressed this difficulty during the interview: "I had difficulty in putting the activities together. In particular, I did not expect that students would have difficulty with the compass."

MPST2 prepared her lesson with respect to the $6^{\text {th }}$ grade learning outcome "To be able to show and explain the invariance of the equality through modeling; and to establish appropriate equations based on a problem" by using concrete materials, showing a two-pan balance model. She planned to make a transition from the balance to the equation concept. The chosen activities for transition, to us, were appropriate, but it was observed that MPST2 had difficulty in performing the second activity that was oriented for forming the equation. She intended to make a transition to the equation concept by forming a two-pan balance model out of paper. She handed papers to the students in order to have them draw a two-pan balance model and then continued her instruction:

Let's fold the paper in half and draw a line down through the folded part. Our papers are our balances. The sides of the folds are our scales. Now, our paper is empty. What should be the sign in the middle? It should be "equal", right? Because if our balance is balanced, the two weights are equal. Because when our balances are balanced in a twopan balance, their weights are equal. 
After these instructions and explanations, MPST2 drew the balance model (see Figure 1), which the students were trying to make, on the board. "Now, I'm going to ask a question. The total price of a book and a magazine is 10 TRY. The magazine is 4 TRY. How can we model this situation on the two-pan balance?" Without waiting for responses from the students, she continued giving the answer by explaining it through the model: "I do not know the price of the book, so I'm going to draw a box on this scale. And the price of the magazine is given, so I'm going to put 4 stamps. Their price equals to 10 TRY so, let's put 10 stamps here."

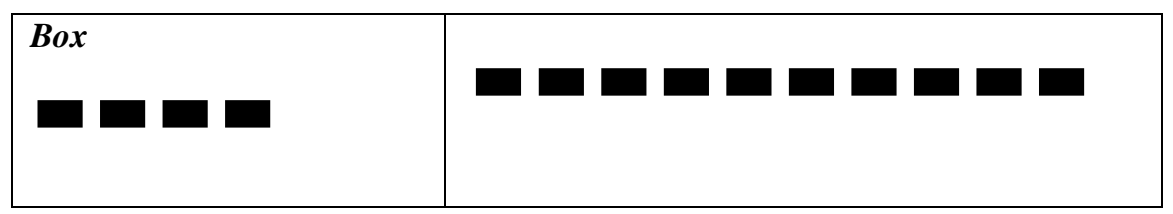

Figure 1: Balance model drawing by MPST2

At the meantime, students got confused and asked some questions including "How did you do that? Why do you put stamps there?" Being aware of these questions MPST2 made further explanations such as "I used 4 stamps instead of $4 T R Y$ " and repeated the explications she had yet done. After these explanations, she wanted to translate what had been done into an algebraic expression along with the class: "Now, I do not know the box. If I call the box $x \ldots x+4=10$. Box $x$; what else was in this scale? 4! What about in between? Equals! Then, we are writing down 10."

While MPST2's lesson was going smoothly at first, the students started getting confused because she did not make any association with the prior knowledge of the students. Therefore, the students had difficulty in understanding the example, and they could not answer the questions that she asked, so this model generated more questions for the students, rather than simplifying the work of MPST2.

As a second activity, MPST2 wanted the students to form a model of the equation $a+(-$ $3)=6$. Even though she realized that the students had difficulty in understanding the first model, she did not revise the following activity in her plan. When passing on to negative modeling without understanding the positive modeling, the students got further confused. When MPST2 was asked during the interview where she had struggled the most in the lesson, she said "it was the modeling part. To be honest, I had difficulty with the a+(-3) modeling. Using straight logic, I went for different colors. I had difficulty in modeling."

This analyze demonstrates that, choosing an appropriate activity does not guarantee its successful application and complications may arise even if the lesson is going smoothly.

\subsection{Conducting Activities in Line with Their Aims}

It was observed that PSTs experienced difficulties in informing students about the intended purposes of the activities, leading activities according to their intended purposes and giving appropriate mathematical explanations for the reached outcomes. Let's illustrate these through some examples:

CPST3 prepared an activity targeted for achieving the $5^{\text {th }}$ grade learning outcome of "converting an improper fraction to a mixed fraction". She brought two whole identical cakes to the classroom and called 13 students to the blackboard: "I'm going to divide this cake [the first one] into 8 equal pieces. I'm going to give them to your friends. So, how many pieces should I divide this second cake into?" 
Some of the students said that they would divide it into 2 pieces, some said 5 and some others said 8 pieces. CPST3 divided the cake into 8 pieces and continued her explanations without paying attention to the students' responses: "We would distribute the 5 pieces to your other friends. What is the fraction that defines the pieces of cake that I distributed?"

Some of the students said that it was 1 and $\frac{5}{8}$, whilst one of them said that it was $\frac{13}{8}$. It was enough for CPST3 that only one of the students gave the right answer; she was not much interested in whether the other students found the correct answer. Although she did not focus on others' responses, this was the main focus of the activity. She did not push the students to think about the problem, so the emphasis was inadequate. Most of the students were not aware of the answer that their friend had given. CPST3 had tried to reach the students by modeling this activity on the board, but the class completely lost the interest in the activity before she concluded that the fractions $\frac{13}{8}$ and " 1 and $\frac{5}{8}$ " are equal. Since she failed to give this explanation, the students had to perform the conversion by using the rule. They converted the fraction by dividing the numerator into the denominator according to the instruction given them, and the activity was forgotten.

On the other hand, the fact that CPST3 had deficiencies in using the mathematics language in instructional explanations and stating concepts mathematically made it difficult for her to conclude the activity according to its intended purposes and summarize it in a way that students could understand. In the interview, when asked where she had the most difficulty, she said: "I had difficulty in explaining the activity clearly; I had done so abstractly." She stated that she was not satisfied with her lesson as well as it was a difficult subject. All the students had lost interest in the activity and it was obvious that the lesson had not been effective.

In another lesson, CPST1 put forward a problem concerning a $5^{\text {th }}$ grade outcome of "finding the whole, based on its given fraction". She started solving a problem and tried to explain a shortcut for solving these kinds of problems: "Well kids, do you see this piece of paper? If I divide the paper into 4 pieces, does it make 4 equal pieces? [The students] Yes." CPST1 continued her explanations after the answer she got from the class: "How do we express one of the pieces as a fraction?" Most of the students who knew about "half" and "quarter" said the answer was 1/4. CPST1 continued her explanations and questions: "I put nuts on this one piece of paper. If there are 4 nuts on the $1 / 4$ part, how do we find how many nuts there are in total? There are 4 nuts, we multiply them by the denominator and we find 16, right?" CPST1 started to solve the problem before the students understood what the problem was; it was not clear what was needed to be solved, and the students did not know what was being modeled. While the modeling was done to ease the transition to conceptual information, it did not affect the solution of the problem. Students understood that they could find the solution by multiplying with the denominator based only on the rule; the answer to why such was the case was not revealed. CPST1 completed her explanations by generalizing: "In order to find the value of the whole based on a given fraction, we multiply the number with the denominator of the fraction and divide it into the dividend."

This explanation led students to learn about the rule and was not enough for their conceptual understanding. At this point, one of the factors that affect the work of CPST1 is that she started the solution without informing students about the intended purpose of the activity. Additionally, her deficiency in conceptual knowledge of the fractions affected her practices negatively. While giving explanations according to the rule, she stayed on the procedural knowledge path.

On the other hand, it was thought-provoking that some PSTs believed that even though the lessons had not been comprehended by the students, their lessons were productive simply because they had used concrete materials. In the interview with CPST1, it is understood that she thought the lesson was productive. To the question "if you wanted to teach this lesson again, 
where would you make a change?", she replied "There is nothing that I would want to change; I was satisfied with the lesson. I demonstrated with concrete materials." And when we asked whether the lesson was productive for the students, she replied "I divided the apple, showed them the nuts. The problem was, I thought I was meeting the goals of two lessons in one."

In this instance, one of the factors which negatively impacted the PSTs' work was their lack of conceptual knowledge about fractions; this affected how they performed the chosen activities.

This analysis showed that while PSTs are performing activities, they lack the ability to instruct their students about the learning purposes, to sum up the lessons, to conclude the activities according to the learning outcome, or to make mathematical explanations that are appropriate for the expected outcomes.

\subsection{Easing the Transition between Activities}

One of the areas of difficulty for the PSTs was easing the transitions between activities. Trying to move to other activities for teaching another subject without questioning whether the students have reached the learning goal at the end of the previous activity can make the lessons too demanding for the students. It appears that teacher guidebook is one of the reasons that cause the teacher candidates to jump from one issue to another. In fact, since the teacher guidebook provided the activities in detail, PSTs made use of this guidebook when planning the learningteaching process and tried to perform all of the activities that they had chosen from the book to teach in one lesson time.

MPTS4 performed an activity related to the following $6^{\text {th }}$ grade outcome: "regions that an angle dissects in a plane". It was the first time that the students were working with the concept of angles at this grade. In order to motivate the students for the lesson, MPTS4 tried to associate the angle concept with daily life. As a first activity he chose an activity which involved forming an angle on tracing paper. He distributed tracing papers to the students and asked them to form angles: "In our last lesson, we learned how to determine a point. Everyone, determine a point by folding. [...] Is everyone settled? We determined the point, right?" He started asking questions about the components of angle before the students had finished the folding activity: "What is a ray, kids, do you know? What is a ray?" He went on with an explanation without waiting for the students to answer:

A ray starts from one point and continues to infinity. For example, assume that here is point A, it continues by extension here. [...] What is an angle, kids? Does anyone know the definition of an angle? [Silence] So, you do not know what an angle is. The definition of an angle is the union of two rays that have the same origin.

He gave the definition of the concept of angle and moved suddenly to talking about the regions that the angle forms:

Now, draw two rays starting from one point. Form an angle from the end point of these two rays. [...] OK friends, is the angle formed? Now, this angle has regions, the inner region and exterior region; but how do we think of the inner region and exterior region? Think of your heads as a point and open your arms; this is the inner region. Your back is the exterior region.

Then he moved on to a different activity before completing the first activity, and then moved back to the first activity. Since there was no unity in the process of the lesson, he had difficulties in terms of classroom management. The fact that he answered his own questions about the activity without waiting for the students to respond and that he moved abruptly to the next activity made it difficult for the students to join in or to follow the next activity. The 
students lost interest, and he had to raise his voice in order to get their attention again. $\mathrm{He}$ expressed this situation in the interview:

The lesson was not easy for me. Classroom management was difficult. [...] In the second lesson, I was a bit harsh, and then they went silent. Once I got them to be silent, then I had difficulty involving them in the subject. [...] Getting the students to be quiet is not an issue, but I had difficulty in keeping them involved in the lesson. I did not know how to balance the two.

As for MPST3, it was observed that she was more successful than the other PSTs in teaching. She did not hurry in easing the transition between the subjects, and she could perform mid-evaluations in the course of a lesson. MPST3 performed her lesson plan concerning the $6^{\text {th }}$ grade learning outcome of "describing two lines on the same plane with respect to each other". With this aim, she performed a folding activity designed for teaching the concept of parallel lines: "Friends, has everyone got a sheet of paper? First, listen to me carefully and do this together. Let's fold the paper like this. Trace the folds with a pencil. So what is the name of this line?" Most of the students answered the question by saying that it was a straight line and to the questions of "So how many centimeters are there between the lines? Does the distance between the lines change?" the students reply "No." After then, MPST3 drew parallel lines and wrote the definition on the board by illustrating the symbol for parallel lines. At the same time, she kept the students from losing the focus. She completed her activities by giving instructions in a manner which could be understood by the students and she also used questions effectively when required. She made the students repeat the results and wrote them on the board, as well as asking them to make notes in their notebooks. She did not fail to evaluate whether the subject was understood or not. For this topic, she drew a house on the board and asked the students to identify the intersecting, parallel and perpendicular straight lines on the building. In this observed lesson, it was seen that she did not make abrupt transitions when moving between subjects and did not rush with her explanations. In the interview, she mentioned that she had designed the lesson all-inclusively and written down everything that she was going to do in the class:

I was able to perform everything I had planned. I wrote every possible situation in detail. For example, I am going to ask this question. Then I am going to call students on the board... If the students could answer I am going ask that question. [When preparing my plan] I drew the shapes, I wrote expressions that I was going to use. I wrote all of it.

Unlike other PSTs, MPST3's detailed lesson plan facilitated the classroom management and thus protected her from facing risky situations. Also, this made the course more comprehensible for the students.

\section{DISCUSSION AND RESULTS}

One of the components of PCK is the organization and presentation of the lesson. Many instructional decisions such as selecting, sequencing and applying the activities, deciding representations to be used, and giving instructional explanations form this component. With this regard, this study was conducted to reveal how PSTs performed classroom activities and the difficulties they experienced in this process.

The findings mainly reveal that MPSTs and CPSTs have common problems in teaching practices. They experience difficulties in determining the activities according to prior knowledge of the students, deciding the difficulty level of the activities and sorting them, informing students about the perceived purpose of the activities, conducting activities according to their perceived purposes and making transitions between activities. Additionally, these deficiencies of PSTs affected their in-classroom practices negatively, and resulted in ineffectual lessons and caused 
difficulties in maintaining classroom management. Depaepe et al. (2015) also revealed that both prospective elementary and lower secondary teachers had limited PCK on rational numbers. Our findings also showed that both MPSTs (who are more mathematically trained) and CPSTs (less mathematically trained peers) experienced the same problems and that there is a parallelism between our findings and those of both studies conducted by Depaepe et al. (2015) and Kleickmann et al. (2013).

As the findings of the study made clear, the lessons designed by MPST2 and MPST3 were much more productive than those produced by the other PSTs. The explanations in their plans, the instructions they gave during activities, the questions they asked, and the transitions they made between activities were appropriate. In the interviews with these PSTs, we found that they made their plans in detail and thought more about their application process. This finding is in line with Chan \& Yung (2015) who revealed that reflection is the foundation for PCK development and emphasized teachers' reflection in-action on their own teaching experiences. Also, Hiebert and Morris (2012) state that extensive lesson plans and sharing these plans with colleagues are efficient methods of improving the instruction process. Consequently, since it would support the development of PSTs, more activities on lesson planning in Teacher Training classes can be suggested.

On the other hand, another important finding emerged from our study is that correct comprehension of the learning outcomes and selecting activities accordingly do not guarantee a successful practice. The instructions and explanations PSTs make, their use of mathematical terminology and ignoring the prior knowledge of the students affected the practice process. Depaepe et al. (2015) also noted that PSTs had limited knowledge about instructional strategies and representations. Henningsen and Stein (1997), in a study conducted with teachers, revealed that both an activity might go off track, and the perceived purpose cannot be reached as a result of not explaining what is expected of learners clearly and of giving vague instructions. From this point of view, it is clear that members of faculty of education need to get more involved in inreal-class application of Teaching Practicum courses.

Even if in theory PSTs know how to deal with prior knowledge of the students, they experienced problems in practice. This finding is in line with other studies (such as Duran \& Uşak (2015)) which noted that less-experienced teachers may have difficulties in dealing with students' prior knowledge. Depaepe et al. (2015) also noted that PSTs had limited knowledge about students' misconceptions and difficulties. Plans and learning-teaching processes designed by PSTs revealed that they are not fully aware of the prior knowledge of the students, and they tend to ignore correlating mathematical concepts and operations, consequently fail in maintaining effective classroom practices. Similar results were found by Baki, Baki \& Arslan (2011) as well.

On the other hand, PSTs have also difficulties in 'informing students about the perceived purpose of the activities' and 'conveying activities according to their purposes.' Some PSTs completed the lessons without reaching mathematically the intended purpose. The perceived purpose and the results of the activity and gains of the students could not be determined throughout the lesson. Moreover, it was observed that PSTs have difficulty in expressing their conclusions mathematically after having performed concrete activities. PSTs' lack of mathematical knowledge also negatively affected the conducting of the activity. Generally, PSTs preferred to express the reached results in a procedural way rather than conceptual knowledge. This finding may be construed to show a deficiency in PSTs' CK and this finding has some commonality with Depaepe et al.'s (2015) study which revealed that both prospective elementary and lower secondary teachers had limited CK on rational numbers. Moreover, the lack of skill in modeling the mathematical knowledge and representation techniques of PSTs affects their instructional explanations negatively. Many researchers reveal that teachers, 
especially PSTs, have difficulties in making instructional explanations (Ball, 1990; Inoue, 2009; Kinach, 2002; Thanheiser, 2009). On the other hand, this study pointed out that PSTs needed to work on improving their instructional explanations before Teaching Practicum courses. PSTs should begin Teaching Practicum courses as their mathematical knowledge is at conceptual knowledge level. During their education, in Mathematics Teaching and Special Teaching Methods courses, they should be prepared to use instructional explanations using especially different representations and mathematics terminology.

PSTs made sudden transitions between subjects or activities without making sure that learners comprehended what they teach or without questioning whether or not the learners reached a conclusion. Horoks and Robert (2007), in their study, emphasized similar issues by pointing out that most of the problems encountered during activities are because of the lack of evaluation skill of teachers. Similarly, in our study it was observed that PSTs experienced problems in interacting with learners mathematically while applying activities. They fail to arrange how and when to ask questions to learners that will make them think mathematically. When they ask questions, they give the answers before waiting for learners to answer and ask questions to make learners confirm what they did. However, as Duran \& Uşak (2015, p. 553) stated "teachers with a broader knowledge address more questions, pay more attention to students' alternative explanations or gives more alternative explanations for the students."

As a conclusion, this study showed that both groups of PSTs experienced difficulties when they apply learning activities they designed. Also, the study clearly revealed that, PSTs could not reflect their theoretical knowledge into practice with the current Teaching Practicum courses and this course needs to be improved. For example, the teacher educators' attendance in PSTs' practice only once or twice in a semester is not enough for PCK development. It would be more helpful for PSTs if their educators attend their real classroom practices more frequently, work cooperatively with them, support them in the lesson planning stage, reflect on their practices and give them feedback.

\section{REFERENCES}

Ann, S., Kulm, G. \& Wu, Z. (2004). The pedagogical content knowledge of middle school mathematics teachers in China and the U.S. Journal of Mathematics Teacher Education, 7, 145-172.

Artzt, A. F. \& Armour-Thomas, E. (1999). A cognitive model for examining teachers' instructional practice in mathematics: A guide for facilitating teacher reflection. Educational Studies in Mathematics, 40, 211-235.

Baki, A., Baki, M., \& Arslan, S. (2011). Prospective primary school teachers' knowledge of their students: the case of mathematics. In B. Ubuz (Ed.), Proceedings of the 35th PME, vol.1, (pp.123-126). Ankara, Turkey.

Ball, D. L. (1990). Halves, pieces, and twoths: Constructing representational context in teaching fraction. National Center for Research on Teacher Education, Michigan State University.

Ball, D. L. \& Bass, H. (2003). Toward a practice-based theory of mathematical knowledge for teaching. In B. Davis \& E. Simmt (Eds.), Proceedings of the 2002 Annual Meeting of the Canadian Mathematics Education Study Group, 3-14. Edmonton, AB: CMESG/GCEDM.

Ball, D. L. \& McDiarmid, G. W. (1990). The subject matter preparation of teachers. In W. R. Houston, M. Haberman, \& J. Sikula (Eds.) Handbook for research on teacher education (pp. 437-449). New York: Macmillan.

Ball, D. L., Thames, M. H. \& Phelps, G. (2008). Content knowledge for teaching: What makes it special? Journal of Teacher Education, 59(5), 389-407.

Baxter, J. A. \& Lederman, N. G. (1999). Assessment and measurement of pedagogical content knowledge. In J. GessNewsome \& N.G. Lederman (Eds.), Examining pedagogical content knowledge (147-162). Dordrecht: Kluwer Academic Publishers.

Borko, H. \& Putnam, R. (1996). Learning to teach. In D. Berliner. \& R. Calfee (eds.), Handbook of Educational Psychology (p.673-708). New York: Mcmillan.

Chan, K. K. H. \& Yung, B. H. W. (2015). On-site pedagogical content knowledge development. International Journal of Science Education, 37(8), 1246-1278. 
Charalambous, Y. C., Hill, H., C. \& Ball, D. L. (2011). Prospective teachers' learning to provide instructional explanations: How does it look and what might it take? Journal of Mathematics Teacher Education, 14(6), 441463.

Depaepe, F., Torbeyns, J., Vermeersch, N., Janssens, D., Janssen, R., Kelchtermans, G., Verschaffel, L. \& Van Dooren, W. (2015). Teachers' content and pedagogical content knowledge on rational numbers: A comparison of prospective elementary and lower secondary school teachers. Teaching and Teacher Education, 47, 82-92.

Duran, M., \& Usak, M. (2015). Examining the pedagogical content knowledge of science teachers who have different teaching experience about acids and bases. Oxidation Communications, 38(1A), 540-557.

Fennema, E. \& Franke, M. L. (1992). Teachers' knowledge and its impact. D. A. Grouws (eds.), Handbook of Research on Mathematics Teaching and Learning (p. 147-164). New York: Macmillan.

Fernandez, C. (2014). Knowledge base for teaching and Pedagogical Content Knowledge (PCK): some useful models and implications for teachers training. Problems of Education in the Twenty First Century, 60, 79-100.

Grossman, P. (1990). The making of a teacher: Teacher knowledge and teacher education. New York, NY: Teachers College Press.

Hashweh, M. Z. (2005). Teacher pedagogical constructions: A reconfiguration of pedagogical content knowledge. Teachers and Teaching: Theory and Practice, 11(3), 273-292.

Hennigsen, M. \& Stein, M. K. (1997). Mathematical tasks and student cognition: Classroom-based factors that support and inhibit high-level mathematical thinking and reasoning. Journal for Research in Mathematics Education, 28(5), 524-549.

Hiebert, J., \& Morris, A. K. (2012). Teaching, rather than teachers, as a path toward improving classroom instruction. Journal of Teacher Education, 63(2), 92-102

Hill, H. C., Sleep, J. M., Lewis, J. M. \& Ball, D. L. (2007). Assessing teachers' mathematical knowledge: What knowledge matters and what evidence counts? In F. Lester (Ed.), Handbook for Research on Mathematics Education (2nd ed). (pp. 110-155) Reston, VA: National Council of Teachers of Mathematics.

Horoks, J. \& Robert, A. (2007). Tasks designed to highlight task-activity relationships. Journal of Mathematics Teacher Education, 10, 279-287.

Inoue, N. (2009). Rehearsing to teach: content-specific deconstruction of instructional explanations in pre-service teacher training. Journal of Education for Teaching, 35(1), 47-60.

Kinach, B. M. (2002). A cognitive strategy for developing pedagogical content knowledge in the secondary mathematics methods course: toward a model of effective practice. Teaching and Teacher Education, 18, 51-71.

Kleickmann, T., Richter, D., Kunter, M., Elsner, J., Besser, M., Krauss, S., et al. (2013).Teachers' content and pedagogical content knowledge: the role of structural differences in teacher education. Journal of Teacher Education, 64, 90-106.

Leong, K. E., Meng, C. C., \& Abdul Rahim, S. S. A. (2015). Understanding Malaysian pre-service teachers' mathematical content knowledge and pedagogical content knowledge. Eurasia Journal of Mathematics, Science \& Technology Education, 11(2), 363-370.

Loughran, J. (2006). Developing a pedagogy of teacher education: Understanding teaching and learning about teaching. London: Routledge.

Lowery, M. N. V. (1998). Construction of teacher knowledge in context: Preparing elementary teachers to teach mathematics and science. Unpublished doctoral dissertation. Texas A\&M University, College Station, TX.

Magnusson, S., Borko, H. \& Krajik, J. (1999). Nature, sources, and development of pedagogical content knowledge for science Teaching. In J. Gess-Newsome, \& N.G. Lederman (Eds.), Examining pedagogical content knowledge (pp. 95-132). Dordrecht: Kluwer Academic Publishers.

Mapolelo, D. C. (1999). Do pre-service teachers who excel in mathematics become good mathematics teachers? Teaching and Teacher Education, 15, 715-725.

Marks, R. (1990). Pedagogical content knowledge: From a mathematical case to modified conception. Journal of Teacher Education, 41, 3-11.

Nilsson, P. (2008).Teaching for understanding: The complex nature of pedagogical content knowledge in pre-service education. International Journal of Science Education, 30(10), 1281-1299.

Park, S. \& Oliver, S. (2008). Revisiting the conceptualisation of pedagogical content knowledge (PCK): PCK as a conceptual tool to understand teachers as professional. Research in science Education, 38, 261- 284. 
Shulman, L. S. (1986). Those who understand: Knowledge growth in teaching. Educational Researcher, 15(2), 4-14.

Shulman, L.S. (1987). Knowledge and teaching: Foundations of the new reform. Harvard Educational Review, 57, 122.

Staley, K. N. (2004). Tracing the development of understanding rate of change: A case of changes in a pre-service teacher's pedagogical content knowledge. Unpublished doctoral dissertation. North Carolina State University, Raleigh, NC.

Thanhieser, E. (2009). Pre-service elementary school teachers' conceptions of multi-digit whole numbers. Journal for Research in mathematics Education, 40, 252-281.

Van Driel, J. H., Verloop, N. \& de Vos, W. (1998). Developing science teachers' pedagogical content knowledge. Journal of Research in Science Teaching. 35(6), 673- 695.

Yeşildere, S., Akkoç, H. (2010). Matematik ögretmen adaylarının sayı örüntülerine ilişkin pedagojik alan bilgilerinin konuya özel stratejiler bağlamında incelenmesi [Examining pre-service mathematics teachers' pedagogical content knowledge of number patterns with regard to topic-specific strategies]. On Dokuz Mayls University, Journal of Education, 29(1), 125-149.

\section{Uzun Özet}

Araştırmalar matematiksel kavramları bilmenin o kavramları öğretebilmek için tek başına yeterli olmadığını ve öğretmenlerin Alanı Öğretme Bilgisi (AÖB) olarak adlandırılan bir bilgiye sahip olması gerektiğini vurgulamaktadır. Konu alanı bilgisinden öteye giden ve derinleşen AÖB, birçok araştırmacı tarafindan etkili öğretim yapan bir öğretmenin rolünü tanımlamada en önemli bileşen olarak görülmektedir (Ann ve diğerleri, 2004; Ball, 1990; Magnussan, Borko ve Krajik; 1999; Nilson, 2008). Bu bilgi, öğretimi yapılan konunun öğrenci tarafından nasıl kazanıldığının bilinmesini, işlevsel sorular sorulmasını, öğrenci öğrenmelerinin değerlendirilmesini, öğrenme öğretme sürecinin düzenlenmesini, yönetilmesini, problemlerin seçilip organize edilmesini, etkili temsil biçimlerinin kullanılmasını ve uygun öğretimsel açıklamaların yapılmasını içeren oldukça kapsamlı bir yapıdır (Ball ve Bass, 1993; Magnussan ve diğerleri, 1999; Shulman, 1986,1987).

Bir çok araştırmacı AÖB'nin kavramsal çerçevesini ortaya koymak amacıyla çalışmalar yürütmüştür (Ball ve diğerleri, 2008; Grossman, 1990; Hashwesh, 2005; Loughran, 2006; Magnusson ve diğerleri, 1999; Marks, 1990; Shulman, 1986,1987; Van Driel ve diğerleri, 1998). AÖB için farklı araştırmacılar farklı bileşenler (öğrenciyi tanıma, Ölçme-değerlendirme, içeriğin hazırlanması ve sunumu,...) belirlese de birçoğunun üzerinde hemfikir olduğu bileşenlerden biri dersin organizasyonu ve sunumudur. Bu bağlamda etkinliklerin seçimi, sıralanması, uygulanması, temsil biçimlerinin belirlenmesi ve bütün bu yapılanların öğrencinin düşünme sürecini nasıl destekleyeceğinin bilinmesi gibi etkinlikler AÖB'nin önemli unsurlarıdır (Baki ve diğerleri, 2011; Ball ve Mcdiarmind, 1990; Grossman, 1990; Marks, 1990; Shulman, 1986, 1987; Staley, 2004).

Dersin organizasyonu ve sunumu bileşeni ile ilgili sayılabilecek birçok araştırma (Artz ve ArmourThomas, 1999; Kahan ve diğerleri, 2003; Mapolelo, 1999; Yeşildere ve Akkoç, 2010;) öğretmen adaylarının bu alanda bazı zorluklar yaşadığını söylese de öğretmen adaylarının yaşadıkları bu zorlukların AÖB bileşenleri bağlamında ayrıntılı ve sistematik olarak incelenmediği görülmektedir. Bu çalışma, öğretmen adaylarının tasarladıkları öğretme etkinliklerini öğrencilere ulaştırma sürecinde ne gibi zorluklar yaşadıklarını AÖB bileşenleri bağlamında ortaya koymak amacıyla yürütülmüştür.

Bu çalışma 4 sınıf ve 4 ilköğretim matematik öğretmeni adayı ile Öğretmenlik Uygulaması dersi kapsamında yürütülmüştür. Özellikle alanı öğretme bilgisi değerlendirilirken öğretmenin ne bildiği, neye inandığı, ne yaptığı ve hareketlerinin sebepleri ile ilgili bilgiler bir arada ele alınmalı ve birlikte yorumlanmalıdır (Baxter ve Lederman, 1999). Bu nedenle çalışmada veriler gözlemler, yarı yapılandırılmış mülakatlar, alan notları, ders planları gibi farklı kaynaklardan toplanmış ve birlikte yorumlanmıştır. Öğretmen adaylarıyla ayrıca okullardaki uygulamalarını yaptıkları gün içerisinde yansımalarını almak için yarı yapılandırılmış mülakatlar yapılmış ve mülakatlar ses alma cihazı ile kayıt altına alınmıştır. Çalışmada her bir öğretmen adayının farklı günlerde gerçekleştirdiği 2 ders sunumu gözlenmiş ve sınıf içi etkileşim dijital kayıt altına alınarak transkript edilmiştir. Araştırmacı gözlemleri sırasında alan notlarını geniş çaplı olarak alırken aynı zamanda öğretmen adaylarının matematiği öğretme bilgisi açısından öğrenci karşısında sıkıntıya düştüğü, öğrenciye ulaşamadığı, dersin verimsiz geçtiği, sınıf kontrolünü kaybettiği ve matematiksel olarak kazanım elde edemediği durumları açık olarak yazmıştır. 
Gözlemler, alan notları, mülakatlar ve ders planları birlikte ele alınarak gömülü teori (grounded theory) yaklaşımıyla kodlamalar yapılarak 3 tema ortaya çıkartılmış ve bulgular bu temalara bağlı kalınarak sunulmuştur: i) Etkinliklerin seçimi ve sıralanması, ii) Etkinliklerin amacından haberdar olma, etkinliklerin amacından öğrencileri haberdar etme ve etkinlikleri amaçları doğrultusunda sonuçlandırma (toparlama) ve iii) Etkinlikler arasındaki geçişin sağlanması.

Çalışmanın sonuçları, her iki gruptaki öğretmen adaylarının öğretim etkinliklerini uygulama sürecinde matematiği öğretme bilgisi bağlamında benzer sıkıntılar çektiklerini ortaya koymaktadır. $\mathrm{Bu}$ sonuçlara paralel olarak Depaepe ve diğerleri (2015) yaptıkları çalışmada ilk ve ortaokul öğretmen adaylarının rasyonel sayılar konusundaki MÖB'lerinin yetersiz olduğunu ortaya koymuşlardır. Bu bağlamda öğretmen adaylarının öğrenme etkinliklerini belirleme, etkinliklerin amacından haberdar olma, öğrencileri haberdar edebilme, etkinlikleri amaçları doğrultusunda toparlayabilme, etkinlikler arasındaki geçişleri ayarlama gibi hususlarda sıkıntılar yaşadıkları görülmüştür. Ayrıca öğretmen adaylarının öğrenme etkinliklerini tasarlarken kolay ve zorluk durumlarını belirlemede, kolaydan zora doğru ve öğrencinin ön bilgisine dayanarak etkinlikleri sıralamada güçlükler yaşadıkları görülmektedir. Çoğu zaman öğretmen adayları, seçtikleri etkinlikler arasındaki geçişleri yapmadan, öğrencinin yapılanları anlamlaştırmasını beklemeden ve etkinlik sonucunda öğrencinin beklenilen hedefe ulaşıp ulaşmadığı sorgulanmadan farklı bir özelliğin veya konunun öğretimine yönelik etkinliklere keskin geçişler yapmaktadır. Böylece öğretmen adaylarının girdikleri dersler yapılanları takip etmede ve anlamada zorlanan öğrenciler için çok yoğun bir ders haline gelmektedir. Elde edilen bu sonuçlar, Depaepe ve diğerleri (2015) and Kleickmann ve diğerleri (2013) tarafindan ortaya konan 'daha iyi bir matematik eğitimi almış ilköğretim matematik öğretmen adaylarının daha az matematik eğitimi almış sınıf öğretmeni adaylarıyla benzer sorunlar yaşadığı' sonucuyla da paralellik göstermektedir.

Öğretmen adaylarının başarılarını olumsuz yönde etkileyen birçok faktör ortaya çıkarılmıştır. Bu faktörlerden biri ögretmen adayların kazanımları derinlemesine anlamadan etkinlik seçme yolunu tercih etmeleridir. Öğretmen adaylarının verimli olmalarını olumsuz etkileyen diğer durumlar da öğretmen adaylarının etkinliklerin amacından haberdar olmamaları, öğrencileri etkinliklerin amacından haberdar edememeleri ve etkinlikleri amaçları doğrultusunda toparlayamamalarıdır. $\mathrm{Bu}$ anlamda öğretmen adaylarına yardımcı olmak için kazanımların ne ifade ettiğine yönelik çalışmalar matematik öğretimi derslerinde daha fazla yer bulmalıdır.

Bununla birlikte, kazanımların doğru anlaşılıp doğru etkinlik belirlenmesi de uygulamanın iyi olacağını garanti etmemektedir. Öğretmen adaylarının verdiği yönergeler, kullandığı ifadeler, matematiksel terminolojiyi kullanma, öğrencinin ön bilgisine dikkat etme gibi hususlar da uygulama sürecini etkilemiştir. Öğretmen adaylarının belirlenen bu yetersizlikleri sınıf içi uygulamalarına olumsuz olarak yansımış ve öğrencilerin verimsiz dersler geçirmesine sebep olmuştur. Ayrıca, bu durum öğrencilerin matematiksel anlayışını olumsuz yönde etkilemekte ve öğretmen adaylarının sınıf hâkimiyetlerini zorlaştırmaktadır.

Çalışma ayrıca bazı öğretmen adaylarının diğerlerine oranla daha başarılı olduklarını ve daha verimli bir ders süreci geçirdiklerini ortaya koymuştur. $\mathrm{Bu}$ öğretmen adaylarının planlarındaki açıklamalar, planladıkları etkinlik ve yönergeler, öğrencilere sordukları sorular, aralardaki geçişler daha yerli yerindeydi. Yapılan mülakatlar bunun temel nedeninin bu öğretmen adaylarının uygulama süreci üzerinde ayrıntılı düşünmelerinden ve ders planlarını kapsamlı yapmalarından kaynaklandığını ortaya koymuştur. Bu da öğretmen adaylarının kapsamlı plan yapmaya özendirilerek karşılaşacakları sıkıntıların asgariye indirgenebileceğini ortaya koymaktadır. 